\title{
CAPITAL MARKET DEVELOPMENT AND ECONOMIC GROWTH: AN ARDL APPROACH FOR SAUDI ARABIA, 1985-2018
}

\author{
Abdulaziz Hamad ALGAEED \\ Department of Finance and Banking, College of Business Administration, \\ Dar Al-Uloom University, Riyadh, Saudi Arabia
}

Received 09 January 2020; accepted 22 May 2020

\begin{abstract}
The aim of this paper is to analyze and test the effects of capital market development on the per-capita GDP growth in Saudi Arabian economy covering the period of 1985-2018. An ARDL, FMOLS and Johansen tests are implemented. The stock market indicators: share price index, capitalization, liquidity, number of share transactions, and number of shares are employed using a $\log$-linear eclectic model designed to fit the availability of data. Capitalization and liquidity came up with negative signs, contrary to the findings of lots of studies in economic literature. However, the share price index, number of shares traded, and the ratio of number of share transactions had the right signs as expected a priori. The findings raise serious questions about the size of the market, the steps and efforts that have been taken to deepen the capital market and their consequences on the function and potency of capital market in fostering per-capita GDP growth. Applying Granger causality test, share price index, market capitalization and number of shares traded do not granger cause per-capita GDP. They are significant at 5 percent level. Capital market authority (CMA) should draw a road map to accelerate deepening the capital market in order to serve economic growth.
\end{abstract}

Keywords: capital market, ARDL, FMOLS, capitalization, economic growth, stock shares, percapita GDP, Saudi Arabia.

JEL Classification: C13, C22, G15, E22.

\section{Introduction}

There has been a disagreement among economists regarding the relationship between financial development and economic growth across countries. Capital mobility on the global levels, does support the long-run growth. However, such mobility yields different consequences like appreciation of the local exchange rate, assets prices fluctuations and the sudden stop of international capital inflows. Countries faced with such consequences try to counter it by using macroeconomic measures, for example taxes and direct capital control. The best way to face the negative consequences is to collaborate with other nations. Looking at the differ-

\footnotetext{
*Corresponding author. E-mail: ibngaeed@outlook.com
} 
ences between developed and less developed countries, one notices that financial services, are practiced safely and efficiently, while in less developed countries it is likely to be less efficient. However, consideration of the effect of the financial sector on economic growth is set to be factual. According to Kargbo and Adamu (2009), a huge body of literature has risen following the famous work of Schumpeter (1911) where he pointed out that productive and growth enhancing the impacts of services rendered by well-developed financial institutions. Furthermore, he asserted that financial intermediaries are the corner stone in fostering economic growth through providing services such as: mobilizing savings, monitoring and appraising investments and pooling risks etc. By and large, Ouandlous (2010) asserts that "The implementation of capital markets requires time and more importantly cooperation between the government authorities and the private sector. I believe that the efficient functioning of capital markets presupposes a favorable economic and political environment and a corresponding appropriate institutional support for this environment".

The main role of the capital market is to raise finance by different institutions. Raising finance will go through issuing a variety of securities. Short-term or working capital is channeled through borrowing from money market. This happens by issuing various securities such as bills, promissory notes, etc. On the other hand, long term funds or fixed capital is raised through companies by issuing shares and bonds. Therefore, Capital market serves a major beneficial role for domestic economy. Businesses need finance rendered from local market. It also offers alternative sources of fund in addition to a better pricing and longer maturities. Riskier businesses could be funded through the capital market, whereas traditional banking cannot offer. Moreover, government could access funds from local market so that risk and inflation are managed better. In addition to mentioned, capital market offers opportunities for savers and investors with better return through variety of services that reduce risk and diversify portfolio especially for institutional investors. Acceleration of economic growth require better institutions which need finance through capital market.

The financial system in a country consists of three functions: payment system, allocation of resources, and managing risk. By the same token, the financial market performs the exchange of assets through capital market, money markets, currency markets, commodities markets, mortgage markets and derivatives markets. Likewise, Levine (1997) has suggested that financial intermediaries could play a major role in economic growth through several means. Easy payment services help easing reciprocate of goods and services, channel savings from investors, efficiency in allocating savings through availability of information, monitoring investments and reducing intertemporal risk (Caporale et al., 2009). The outcomes of major empirical studies assert that financial intermediaries affect positively economic growth of a nation. For this purpose, capital markets' integration is found to positively affect economic growth in European union countries (Oprea \& Stoica, 2018). These analyses took into consideration that there are three important elements of financial development as a catalyst of economic advancement. The first is mobilizing savings. Secondly, is fostering economic activities and thirdly, the size of the financial intermediaries (Iheanacho, 2016).

Historically, the development of Saudi capital market can be traced unofficially to the early fifties and continued working until eighties when Saudi government set its regulations. The Royal Decree number $(\mathrm{M} / 30)$ announced officially the foundation of capital market 
authority (CMA) in 2003. CMA is a governmental body with financial, legal, and administrative independence. Its role is to develop and regulate the capital market by issuing regulations with the objective of promoting investment, transparency, and disclosure standards in all listed companies in the market. In addition, preventing illegal acts in the market to protect investors and spread confidence. As a result of capital market law, Saudi stock market founded as a joint stock market company (TADAWUL) to offer and supervise trading of securities. Additionally, the capital market law established the security depository center with the aim of carrying out transactions of deposits, transfers, etc. Recently, CMA joined the MSCI, FTSE and S\&P. The Saudi market value for example, reached the highest in 2006. After that, variations in the capital market is noticeable (see Figure 1). To further development of capital market, CMA formed the secondary market, namely NOMU which is established in 2017 in order to encourage small companies to dare and invest in capital market.

The research problem addresses the paucity of studies on the Saudi financial sector, specifically capital market and its association with economic growth, namely GDP growth. This motivated me to offer a recent and a comprehensive study. Generally speaking, studies forwarded towards the relationship between financial development and economic expansion, concluded that, this correlation is different in comparison with developed economies because of the dominance of the oil sector on economic activities (Samargandi et al., 2014; Quixina \& Almeida, 2014; Bakwena \& Bodmanm, 2011; Cevik \& Rahmani, 2013; Nwani et al., 2016; Okene \& Ndubuisi, 2017; Nwamuo, 2018). This work introduces the need to present a recent study that considers the main factors of capital market which expected to affect economic growth. The factors are, the market value, number of shares traded, value of shares, number of share transactions and the share price index. This study will try to answer the question of whether the capital market affected economic growth and by how much. Financial development will not be discussed in length.

The objective of this research is to test theoretically and empirically the development and participation of Saudi capital market in economic growth. The expected outcomes of this work will be valuable for researchers, policy makers, and who is interested in investing in the capital market or fond of the development of the Saudi capital market.

The remaining of this paper is as follows. Section 1 reviews and analyzes the theoretical and empirical literature. Section 2 deals with material and methods which include descriptive statistics and the estimation of the model. Section 3 discusses the empirical findings and their interpretations, and last section concludes the paper with policy suggestions.

\section{Review of related and empirical literature}

According to Levine (1997), a huge body of literature revealed a robust and positive correlation between the development and functioning of financial systems and long run economic expansion. He asserted that there is a need not to take aside with pros and cons of the association between financial development and GDP growth. Nowadays this cautious stand might be overwhelmed by empirical analyses which confirm the role of financial intermediaries in economic growth. Fisman and Love (2004) suggested that in the long run economies with high rates of financial development will allocate more resources to industries because they 
rely on outside sources of finance as a result of comparative advantage. However, in the short run financial development helps in reallocating resources to industries regardless of the dependence on outside finance. Furthermore, contribution of financial development is discussed in the literature, Caporale et al. (2009) reviews the relationship between financial development and economic growth in in ten EU countries for the period of 1994-2007. They concluded that stock and credit markets are not mature enough and their participation in economic growth is minimal. Furthermore, Benczur et al. (2019) confirmed the existence of non-linear robust impact of financing on growth in OECD, EU, and EMU countries. Additionally, Cevik and Rahmati (2013) asserted that empirical estimations are different depending on different model specifications. They found statistically negative effect of financial development on non-oil output growth. On the contrary, Ho (2019) confirms the positive impact of banking sector and economic growth on the development of stock market in South Africa. On the other hand, applying vector autoregressive estimation (VAR), the impact is found to be insignificantly negative. In addition, Edweib et al. (2013) examined the effect of stock market on economic growth for Libyan economy for the period of 1970-1999. Based on the response of brokers, employees, and investors, there will be a positive contribution and strong effect of the stock market on economic growth. They suggested policies and regulations which will enhance the stock market and make it attractive to local and foreign investors. On the Omani case, Alam and Hussein (2019) confirmed the existence of positive effect of stock market on economic advancement. Furthermore, Havranek et al. (2013) worked with 1334 assessments from 67 studies done on the effects of financial development on economic growth. In aggregated studies, they found positive and significant impact of financial development on economic growth. However, once disaggregated, the assessments vary largely.

In a similar vein, Mukundi (2013) aimed at measuring the relationship between financial deepening and economic growth, namely rate of growth of GDP. 1 percent rise in liquid liabilities would result in 0.17 percent drop in GDP. A rise in stock turnover by 1 percent would lead to 0.038 percent increase in GDP growth. Furthermore, 1 percent increase in market capitalization would result in an increase in GDP growth by 10 percent. Also, 1 percent rise in private credit would lead to a rise in GDP growth by 5.4 percent. Further, Mhadhbi (2014) re-examined the relationship between financial development and economic growth for 110 countries developed and developing countries. He found that the measure of financial deepening depends positively on economic growth for developing countries, while depends negatively for developed countries. In addition, Ho and Odhiambo (2020) concluded that financial sector positively affects stock market. However, exchange rate and inflation stock market too. Utilizing Markov Switching Model, Rahman et al. (2020) deduced that financial development increases economic growth in high and low economic regimes in Pakistan. Just as important, Quixina and Almeida (2014) found that causality is running from oil earnings to the other variables. They emphasized that financial development had no significant role in affecting economic growth in Angola. Concerning China, Lei and Mishra (2016) found that Shanghai stock market had a negative long run correlation with economic growth. Furthermore, they confirmed no evidence of association between stock market and real economy. Hence, economic growth stimulates stock market. Likewise, Bakwena and Bodman (2011) 
examined the impact of financial development in 44 oil and non-oil countries for the period of 1984-2003. They found that the powerful impact of financial intermediaries depends on whether the country is an oil-based economy or not. Further, Iheanacho (2016) found that the link between financial development and economic growth is not significant in Nigeria like other oil producing countries.

Further elaborating on the impacts of capital markets on economic development, Brasoveanu et al. (2008) tested the existence of association between capital market development and economic development in Romania. They concluded that capital market advancement is positively associated with economic growth. Similarly, Kehinde et al. (2013) concluded that market index and capitalization are accounted for 33.7 and 44.8 percent of change in real GDP respectively in Nigeria. In an endogenous economic growth view, Flaviabarna and Mura (2010) found that capital market development had affected economic growth in Romania. Similarly, Kolapo and Adaramols (2012) tested for the link between capital market development and GDP growth in Nigeria. They concluded that capital market activities tend to positively influence economic growth. Similarly, Okoh and Eke (2015) examined the relationship between capital market and economic GDP growth in Nigeria and found that capital market variables are related positively and statistically significant to economic growth. On the contrary, Onuora (2019) found no significant positive effect of capital market on GDP growth in Nigeria. Moreover, Ailemen et al. (2016) found that all share index revealed inverse correlation with economic growth, while capitalization, value of transactions and number of deals exhibited positive association with economic advancement. Similarly, Abina and Maria (2019) found that capital market is a strong driver of economic development in Nigeria for the period of 1985-2017. To add more, Nwamuo (2018) pointed out that capitalization and number of deals have a positive impact on economic growth. However, total listed equity and volume of transactions have a negative impact on economic growth in Nigeria between 1981-2016. Further, Acha and Akpan (2019) asserted that causality runs from capital market indicators to GDP and capital market positively affects economic growth in Nigeria for 1987-2014.

Studies discussed the impacts of oil price changes on stock markets, Okene and Ndubuisi (2017) tested empirically the relationship of crude oil price and stock market and economic development for Nigerian economy for the year 1981-2014. Their results revealed the prevailing role of oil sector in the economy and the rustiness contribution of stock market to economic development. Recently, Lenee and Oki (2017) examined the link between capital market development and economic expansion for Mexico, Indonesia, Nigeria, and Turkey (MINT). The study covered the period of 13 years. They concluded that number of shares as a ratio of GDP is the most significantly affect savings and negatively influence GDP for MINT. Indonesia is mostly influenced positively by financial development. In like manner, Idenyi et al. (2017) tested for the effect of capital market indicators on economic development in Nigeria. Results revealed positive and significant linkage between market capitalization and economic growth in the short run. Both market capitalization and total value of shares has revealed negative and insignificant correlation with economic development in the long run. Additionally, Osakwe and Ananwude (2017) concluded that there exists a positive but insignificant association between stock market development and GDP growth in Nigeria. 
Along the same line for non-oil-based economy, Masoud (2013) examined the causality between stock market performance and economic development in Jordan. His study suggests a positive link between stock market and economic development in the Jordanian economy in both short and long run. As can be seen, Osamwonyi and Kasimu (2013) tested causality between stock market development and economic development in three African countries, Kenya, Ghana, and Nigeria. They pointed out that there is no causality between stock market and economic development in Kenya and Ghana. However, unidirectional evidence between stock market development and economic expansion is found in Nigeria. Despite this, Jamil and Shazia (2013) concluded that it could be variables omitted from equation might affect economic development in Bangladesh. Moreover, Ikikii and Nzomoi (2013) found jointly capitalization and trade volume explained 91 percent of changes in economic growth in Keynea. Osho (2014) found that the development in stock market is positively correlated with financial institutions and in turn with economic progress. In contrast, Srinivasan (2014) concluded that stock market indicators influence economic growth positively. Nonetheless, Yadirichukwu and Chigbu (2014) found contradicting results for Nigeria. While two of indices exhibited positive impact, the two others were inversely related to economic growth. Accordingly, Bader (2015) concluded that there is no causal relationship between stock market development and economic growth in Egypt. In like manner, Khetsi and Mongale (2015) found a positive relationship between capital market development and economic growth in South Africa. In a close picture, S. Nordin and N. Nordin (2016) concluded that, there exists unidirectional causality running from stock market to economic development. In addition, Bist (2017) found that capitalization had positive and significant effect on economic development in Nepal. In an interesting work, Coskun et al. (2017) examined the relationship between the development of sub-components of capital market like mutual and pension funds, corporate bond stock, government bonds and economic development for Turkey. They found a long co-integrating linkage between capital market development and economic growth. Moreover, unidirectional causality runs from capital market to economic development. By applying auto regressive distributed lag (ARDL), Markov switching regression and Kalman filter techniques, they concluded that there is capital market asymmetric effect on economic advancement. Although government bond market development is negatively correlated with economic development, aggregate index of sub-components is positively associated with GDP growth. In the same manner, the finding of Qamruzzaman and Wei (2018) supports the theory that market-based development and financial innovation promote economic growth in Bangladesh for 1980-2016. Of equal importance, Wanaset (2018) confirmed the positive effect of stock market development on economic growth in Thailand. Nonetheless, Twerefou et al. (2019) found positive impact of stock market development on economic growth in selected Sub-Saharan African countries.

Empirically, studies that dealt with Saudi case are numbered. Ibrahim (2013) concentrated on the association between financial development and economic expansion for Saudi Arabia for the year 1989-2008. He concluded that bank credit to private sector had a positive and significant influence on economic progress in the long run, rather than in the short run. However, stock market index had the right sign but insignificantly impact in the long run. Furthermore, the sign and the insignificancy are not expected in the short run. Additionally, 
Samargandi et al. (2014) tested the effect of financial development on economic progress in an oil rich country, Saudi Arabia. They found a positive influence of financial sector on growth of non-oil GDP. However, the impact of financial development over the oil sector and aggregated GDP is somewhat misleading. The coefficients are either negative or insignificant. They suggested that financial development overgrowth is different in an oil-based economy. Accordingly, Alghfais (2016) examined the relationship between financial development and economic expansion in non-oil sector in Saudi Arabia for the period of 1985-2015. He used six measures for financial development: non-oil GDP, oil price, government expenditure, inflation, investment, and trade openness. Furthermore, he used banking and stock indicators. Banking indicators cover ratio of M2/nominal GDP, M3/nominal GDP, and the credit to the private sector to GDP. Auto regressive distributed lag (ARDL) performance indicated that there exists a positive and significant impact of financial development on economic progress. Likewise, Bakwena and Bodman (2011) examined the influence of financial development in oil and non-oil countries for the period of 1984-2003. They utilized generalized method of moments (GMM) in a dynamic panel of 44 less developed economies. They found that financial expansion plays a major role in affecting efficiency of investment and hence, the performance of these economies. Furthermore, the powerful effect of financial intermediaries depends on whether the country is an oil-based economy or not. Lastly, Alrassi et al. (2019) pointed out empirically that stock market prices had a positive and significant effect on real economic development in Saudi Arabia during the period of 2010: Q1 till 2018: Q4.

Having reviewed literature, this paper contributes to the literature by analyzing thoroughly the impact of capital market on economic development where this type of analysis rendered for a major oil producer. Therefore, the relationship between capital market indicators and growth in real per-capita income is vital for accelerating economic stability in financial system, and thus, affect real economic growth. Addressing the conformity of findings to economic researchers' outcomes in economic literature is an addition.

\section{Materials and methods}

\subsection{Description of data}

To test the effect of capital market development on economic expansion in Saudi Arabia, descriptive statistics is presented. The main objective of the descriptive statistics analysis is to exhibit summary of the statistics of the main variables under study. It serves to visualize raw data in a meaningful way which helps us in interpreting the raw data. Furthermore, descriptive statistics could be presented in different measures. Measure of central tendency encompasses mean, median, and mode. Other measures of variables cover standard deviation, variance, minimum, maximum variables, kurtosis, skewness and Jarque-Bera (see Table 1).

Looking at data in Table 1, average value of GDP is 1235838 (millions Saudi riyals). In 1985 the value of the GDP is 376318 (millions) and reached the highest value of 1949238 (millions) in the year 2008. Therefore, it declined and rose again to 2949457 (millions) in 2018. Fluctuations reflect the ups and downs in international oil market. Similarly, percapita GDP averaged 49689 (thousands Saudi riyals). It reached the highest in 2014 with value of 95300 (thousands) responding to better oil windfalls. Of equal importance, market 
Table 1. Descriptive statistics of gross domestic product (GDP), Per-capita gross domestic product (PGDP), Total market capitalization (MV), Total number of shares traded (NS), Share price Index (INDEX), Total Volume of Transactions (T), and value of shares (VS) for the period 1985-2018 (source: Saudi Arabian Monetary Agency [SAMA], 2019)

\begin{tabular}{|l|c|c|c|c|c|c|c|}
\hline & GDP & PGDP & INDEX & MV & VS & NS & T \\
\hline Mean & 1235838 & 49688.94 & 4483.758 & 788.6176 & 881262.0 & 22948.97 & 16938129 \\
\hline Median & 710851.5 & 33894.00 & 2474.095 & 278.0000 & 108694.0 & 1214.000 & 819352.0 \\
\hline Maximum & 2949457 & 95300.00 & 16712.64 & 2438.000 & 5261851 & 86006.00 & 96095920 \\
\hline Minimum & 320931.0 & 23973.00 & 646.0300 & 63.00000 & 760.0000 & 4.000000 & 7842.000 \\
\hline Std. Dev. & 920618.0 & 25090.45 & 3743.483 & 737.4445 & 1249130 & 29072.81 & 23294277 \\
\hline Skewness & 0.699789 & 0.651936 & 1.131403 & 0.562589 & 1.863273 & 0.729633 & 1.539649 \\
\hline Kurtosis & 1.880727 & 1.823471 & 4.306536 & 1.841774 & 6.468559 & 1.890120 & 5.235086 \\
\hline Jarque-Bera & 4.549755 & 4.369425 & 9.672047 & 3.693978 & 36.71723 & 4.761831 & 20.51005 \\
\hline Probability & 0.102810 & 0.112510 & 0.007939 & 0.157711 & 0.000000 & 0.092466 & 0.000035 \\
\hline Sum & 42018504 & 1689424 & 152447.8 & 26813.00 & 29962908 & 780265.0 & $5.76 \mathrm{E}+08$ \\
\hline Sum Sq. Dev. & $2.80 \mathrm{E}+13$ & $2.08 \mathrm{E}+10$ & $4.62 \mathrm{E}+08$ & 17946204 & $5.15 \mathrm{E}+13$ & $2.79 \mathrm{E}+10$ & $1.79 \mathrm{E}+16$ \\
\hline Observations & 34 & 34 & 34 & 34 & 34 & 34 & 34 \\
\hline
\end{tabular}

capitalization averaged 789 (millions) and started to progress over time till it reached the highest of 1859 (millions) in the year 2018. During this period capital market authority indulged in encouraging private companies to be part of the market. In the same vein, liquidity indicator averaged 881262 (millions). Its value hiked up to 1660622 (millions) in 2016.

To see the deviation of from the mean, GDP and PGDP had the maximum deviation from the mean, while MV, INDEX had the minimal deviation from the mean with values of 734.4 and 3743.4, respectively. Subsequently, skewness measures symmetry, and thus, all the variables are positively skewed. The high skewed variables are INDEX, VS and T. It could be attributed to higher incremental values. However, the least positively skewed variables are MV, GDP, PGDP. By the same token, Kurtosis measures tailed variables where the high Kurtosis are INDEX, VS, and T. This shows the presence of outliners and the steepness. Furthermore, the asymptotic tendency of the variables can be seen through probability. The $\mathrm{J}-\mathrm{B}$ statistics for the series suggests that the series, INDEX, VS, and T are with probability less than 5 percent. The rest of series may not normally distribute at 5 percent.

The data for this study were gathered and organized from Saudi Arabian monetary agency (SAMA), yearly statistics 2019. In addition, some of the data are sourced and cross checked from capital market authority (CMA).

\subsection{The model}

Following the standard literature, an eclectic model is developed and adopted taking into consideration some of the features of the Saudi economy. To test the impact of capital market indicators on economic development, this paper examines factors affecting economic development based on the forgone analyses of the standard literature. For the most part, all independent variable in literature will not be tested against economic growth due to the lack 
of information about some of the variables. This work will be constructed as a log-linear an eclectic model specified to include the following suitable variables:

$$
\begin{gathered}
\left\{\mathrm{LPGDP}_{t}=\Psi_{0}+\Psi_{1 t} \mathrm{LINDEX}+\Psi_{2 t} \mathrm{LRVS}+\Psi_{3 t} \mathrm{LRMV}+\right. \\
\left.\Psi_{4 t} \mathrm{LRT}+\Psi_{5 t} \mathrm{LNS}+\mathrm{U}_{t}\right\}
\end{gathered}
$$

where: $\mathrm{LPGDP}_{t}$ is the real per-capita GDP; LINDEX $_{t}$ is the share price index index measures the direction of the market; LRVS is the value of shares percent of GDP (proxy for liquidity); LRMV ratio of market value to GDP (proxy for capitalization); LRT is the number of share transactions. Finally, LNS is number of shares traded in the stock market.

Auto regressive distributed lags (ARDL) has been presented and applied first by Pesaran and Shin (1999) with the characteristics of not requiring all variables to be stationary at I (0) or I (1). Although spurious regression is associated with nonstationary data, ARDL model tackles long run association between variables which are not stationary. Dealing with variables with different orders I (0), I (1) or both, this process carries the best solution. The major advantage of this approach is in its identification of co-integrating vectors where there are multiple co-integrating vectors (Nkro \& Uko, 2016). Furthermore, this approach collapses in case of integrated stochastic trend. The $\operatorname{ARDL}(\mathrm{p}, \mathrm{q})$ model can be constructed as unrestricted error correction version as follows:

$$
\begin{aligned}
& \left\{\Delta \mathrm{LPGDP}=\beta_{0}+\sum_{i=1}^{n} \beta_{1 i} \Delta \mathrm{LPGDP}_{t-i}+\sum_{i=1}^{n} \beta_{2 i} \Delta \operatorname{LINDEX}_{t-i}+\sum_{i=1}^{n} \beta_{3 i} \Delta \mathrm{LRVS}_{t-i}+\right. \\
& \sum_{i=1}^{n} \beta_{4 i} \Delta \mathrm{LRT}_{t-i}+\sum_{i=1}^{n} \beta_{5 i} \Delta \mathrm{LNS}_{t-i}+\sum_{i=1}^{n} \beta_{6 i} \Delta \mathrm{LRMV}_{t-i}+\lambda_{1} \mathrm{LPGDP}_{t-1}+ \\
& \left.\lambda_{2} \operatorname{LINDEX}_{t-1}+\lambda_{3} \mathrm{LRVS}_{t-1}+\lambda_{4} \mathrm{LRT}_{t-1}+\lambda_{5} \mathrm{LNS}_{t-1}+\lambda_{6} \mathrm{LRMV}_{t-1} \mathrm{e}_{1 t}\right\} \text {, }
\end{aligned}
$$

where $\beta_{t i}$ with $t=1,2,3,4,5$ and 6 represents short-run dynamic coefficients. The ARDL model includes per-capita GDP (LPGDP), value of shares percent of GDP (LRVS), ratio number of shares transactions to GDP (LRT), number of shares traded (LNS), and the share price index (LINDEX) at time $t$ (see Figure 1). The value of shares proxies market capitalization where it measures the size of the market. Capitalization usually provides opportunities for capital allocations to investment projects. It could be also used as a market liquidity measure besides the number of transactions (LRT) and number of shares traded (LNS). Ordinarily, capitalization is specified as the ratio of market value divided by GDP. Equally important, $\lambda_{1}$ to $\lambda_{6}$ represent the long-run relationships, while $\beta_{1}$ to $\beta_{6}$ represents the shortrun dynamics of our present model. To test for the presence of long-run relationships among the variables LPGDP, LRMV, LRVS, LRT, LINDEX and LNS, bound testing is conducted. F-test value determines the subsistence of co-integration (long-run relationships) among the variables under consideration. Once F-value is higher than upper bound, we reject $\mathrm{H}_{0}$ and there exist co-integrated variables, such that:

$$
\left\{\mathrm{H}_{0}: \lambda_{1}=\lambda_{2}=\lambda_{3}=\lambda_{4}=\lambda_{5}=\lambda_{6}=0\right\} .
$$



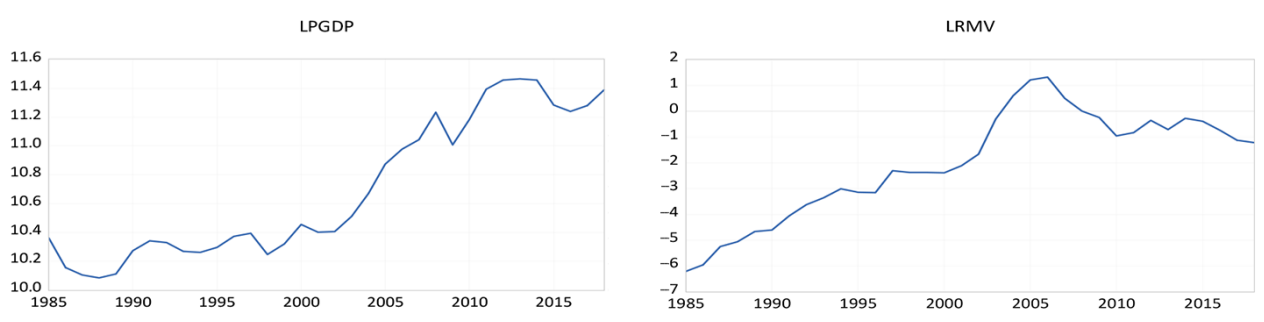

LT
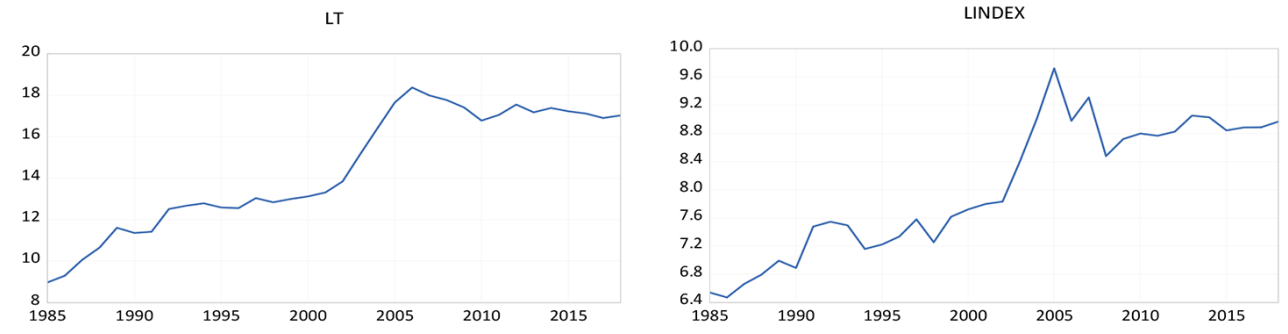

Figure 1. Per-capita GDP, share of market value and transactions to GDP and market index (in log)

In like manner, if F-value is less than lower bound, $\mathrm{H}_{0}$ is accepted and variables are not co-integrated. Hence, in case of no long-run relationships among the variables, then:

$$
\left\{\mathrm{H}_{1}: \lambda_{1} \neq \lambda_{2} \neq \lambda_{3} \neq \lambda_{4} \neq \lambda_{5} \neq \lambda_{6} \neq 0\right\}
$$

The short run correction model relationships presented in this analysis is specified as follows:

$$
\begin{gathered}
\left\{\Delta \mathrm{LPGDP}=\beta_{0}+\sum_{i=1}^{n} \beta_{1 i} \Delta \mathrm{LPGDP}_{t-\mathrm{i}}+\sum_{i=1}^{n} \beta_{2 i} \Delta \operatorname{LINDEX}_{t-\mathrm{i}}+\sum_{i=1}^{n} \beta_{3 i} \Delta \mathrm{LRVS}_{t-\mathrm{i}}+\right. \\
\left.\sum_{i=1}^{n} \beta_{4 i} \Delta \mathrm{LRT}_{t-\mathrm{i}}+\sum_{i=1}^{n} \beta_{5 i} \Delta \mathrm{LNS}_{t-\mathrm{i}}+\sum_{i=1}^{n} \beta_{6 i} \Delta \mathrm{LRMV}_{t-i}+\Theta_{1} \mathrm{ECM}_{t-1}+\mathrm{u}_{1 t}\right\} .
\end{gathered}
$$

It is expected that $\mathrm{ECM}_{t-1}$ with $\Theta_{1}$ is negative and significant indicating that any variations between the dependent and explanatory variables are easily corrected to a stable long run relationship. The negative percentage of disequilibrium of past year will return to long run equilibrium in the following year. Hence, the explanatory variables will come back to the long-run equilibrium at a certain speed given by the magnitude of $\Theta_{1}$.

\subsection{The estimation of the model}

\subsubsection{The ARDL unit root testing}

In economic literature, the Augmented Dickey-Fuller (ADF) and Phillip-Perron (PP) tests are coducted to examine long run relationship stationarity among assigned variables. ADF test is presented as follows:

$$
\left\{\Delta \mathrm{Y}_{t}=\beta_{0}+\beta_{1} \mathrm{Y}_{t-1}+\sum_{j=1}^{k} d j \Delta \mathrm{Y}_{t-j}+\varepsilon_{t}\right\}
$$


where $\varepsilon_{\mathrm{t}}$ is the white noise error term or residual, $\Delta$ is the first difference operator, $\beta_{1}$ is a time series, $\beta_{0}$ is constant and $\mathrm{k}$ is the dependent variable optimum number lags. Thus, a variable is stationary, if the value of assigned coefficient $\Delta$ is less than the critical value of Fuller table. Furthermore, PP unit root test can be performed as follows:

$$
\left\{\Delta \mathrm{Y}_{t}=\beta+\rho \times \mathrm{Y}_{t-1}+\varepsilon_{t}\right\}
$$

As seen from Table 2, all variables are not integrated of order zero I (0), either by ADF or PP tests. However, all variables (LPGDP, LINDEX, LRMV, LRVS, LRT, and LNS) are integrated of the order I (1). This suggests a random walk trend. At the integrated level of one, all variables are significant ranging between land 5 percent level of significance. Having finished the forgone analysis, the strength of Akaike information criteria over other criterion is based on the following fact, 20 different ARDL models are performed. The lower value of AIC will be selected, that is $(3,3,3,3,1,2)$ gives the lowest values of AIC. For the most part, Figure 2, shows the strength of the selected model criteria.

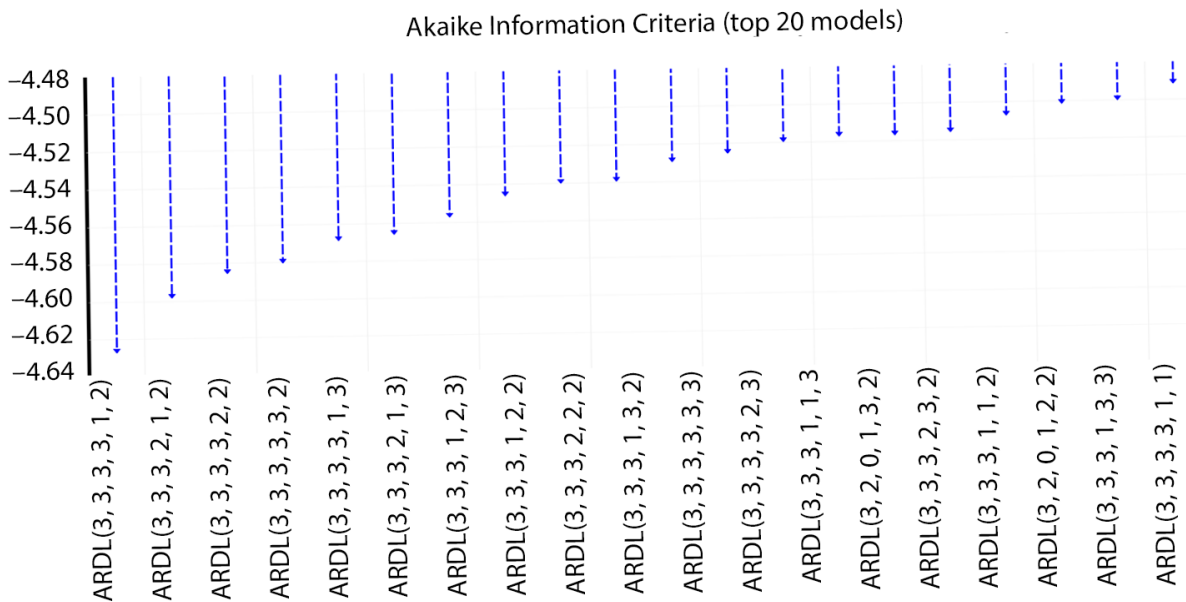

Figure 2. The strength of model selection criteria

Table 2. Augmented-Dickey Fuller and Phillips-Perron tests

\begin{tabular}{|l|c|c|c|c|}
\hline \multirow{2}{*}{} & \multicolumn{2}{|c|}{ Augmented-Dickey Fuller } & \multicolumn{2}{c|}{ Phillips-Perron } \\
\cline { 2 - 5 } & level & $1^{\text {st }}$ Difference & Level & $1^{\text {st }}$ Difference \\
\hline LPGDP & -0.04 & $-5.12^{\star}$ & -0.13 & $-5.15^{\star}$ \\
\hline LINDEX & -1.43 & $-6.82^{\star}$ & -1.33 & $-6.94^{\star}$ \\
\hline LRMV & -2.22 & $-7.82^{\star}$ & -2.15 & $-7.80^{\star}$ \\
\hline LRVS & -2.15 & $-3.45^{\star *}$ & -2.13 & $-3.45^{\star *}$ \\
\hline LRT & -1.97 & $-3.50^{* *}$ & -2.12 & $-3.46^{* *}$ \\
\hline LNS & -2.27 & $-4.50^{*}$ & -2.34 & $-4.68^{\star}$ \\
\hline
\end{tabular}

Note: ${ }^{\star},{ }^{* *}$, and ${ }^{* * *}$ denotes statistically significant at $1 \%, 5 \%$ and $10 \%$ level, respectively. 


\subsubsection{Johansen co-integration test results}

The long run relationship between macroeconomic variables is essential and of interest for policy makers. This is good if there is a harmonious causal movement between the variables. In economic literature, (Hjalmarsson \& Osterholm, 2007), Johansen's methodology starts with VAR of order $\mathrm{p}$ given by:

$$
\left\{\mathrm{Y}_{t}=\mu+\mathrm{A} 1 \mathrm{Y}_{t-1}+\ldots+\mathrm{ApY}_{t-p}+\varepsilon_{t}\right\}
$$

where $\mathrm{Y}_{t}$ is an $\mathrm{n} \times 1$ integrated variables of order on $\mathrm{I}(1)$ and $\varepsilon t$ is an $\mathrm{n} \times 1$ vector of innovations. The VAR can be written as:

$$
\left\{\Delta \mathrm{Y}_{t}=\mu+\Pi \mathrm{Y}_{t-1}+\sum_{i=1}^{p-1} \Gamma i \Delta \mathrm{Y}_{t-1}+\varepsilon_{t}\right\}
$$

where $\Pi=\sum_{i=1}^{p} A i-\mathrm{I}$, and $\Gamma i=\sum_{j=i+1}^{p} A j$.

If coefficient of matrix $\Pi$ has reduce rank $r<n$, then there exists $n \times r$ matrices $\alpha$ and $\eta$ each with rank $r$ such that $\Pi=\alpha \eta^{\prime}$ and $\eta^{\prime} Y_{t}$ is stationary. Johansen proposed two likelihood ratio tests of the significant of these canonical correlation by reduced rank of $\Pi$ matrix: trace test and maximum eigenvalue test, such as:

$$
\begin{aligned}
& \left\{\mathbf{J}_{\text {Trace }}=-\mathrm{T} \sum_{i=r+1}^{n} \ln \left(1-\hat{\lambda}_{\mathrm{i}}\right)\right\} \\
& \left\{\mathbf{J}_{\text {Max }}=-\mathrm{T} \ln \left(1-\hat{\lambda}_{\mathrm{r}+1}\right)\right\} .
\end{aligned}
$$

$\mathrm{T}$ is the sample size and $\hat{\lambda}_{\mathrm{I}}$ is the $i^{\text {th }}$ largest correlation. Johansen's co-integration test necessitates lag length which can be obtained through unrestricted VAR model (Hjalmarsson \& Osterholm, 2007). Tests in Table 3 here used 3 lags depending on unrestricted VAR lag order, LR, FPE, AIC, and HQ. From Table 4, trace statistic test confirms the existence of 5 co-integrated equations at the 1 percent level, while maximum eigenvalues confirm 5 cointegrated equations too. The null hypotheses for the trace and max tests are that, there are no co-integrations between LPGDP, LINDEX, LRVS, LRMV, LRT and LNS. The null hypotheses are rejected, and thus, there exist long-run relationships among the above variables.

Table 3. VAR lag order selection criteria

\begin{tabular}{|c|c|c|c|c|c|c|}
\hline Lag & LogL & LR & FPE & AIC & SC & HQ \\
\hline 0 & -51.43958 & NA & $1.86 \mathrm{e}-06$ & 3.705779 & 3.893325 & 3.796252 \\
\hline 1 & 107.0116 & 245.3438 & $6.37 \mathrm{e}-10$ & -4.194297 & $-2.251475^{\star}$ & -3.560985 \\
\hline 2 & 148.9466 & 48.69868 & $5.77 \mathrm{e}-10$ & -4.577198 & -0.969101 & -3.401049 \\
\hline 3 & 220.8529 & $55.66944^{\star}$ & $1.37 \mathrm{e}-10^{\star}$ & $-6.893737^{\star}$ & -1.620365 & $-5.174749^{\star}$ \\
\hline
\end{tabular}


Table 4. Johansen co-integration test (lags $=3$ )

\begin{tabular}{|c|c|c|c|c|c|c|c|c|}
\hline $\mathrm{H}_{0}$ & $\mathrm{H}_{\mathrm{A}}$ & Eigenvalues & $\lambda_{\text {Trace }}$ & $95 \%$ & $\mathrm{H}_{0}$ & $\mathrm{H}_{\mathrm{A}}$ & $\lambda_{\text {Max }}$ & $95 \%$ \\
\hline \multicolumn{7}{|c|}{ LPGDP } \\
\hline $\mathrm{r}=0$ & $\mathrm{r}=1$ & 0.877119 & 212.2050 & 95.75366 & $\mathrm{r}=0$ & $\mathrm{r}=1$ & 64.99260 & 40.07757 \\
\hline $\mathrm{r}=1$ & $\mathrm{r}=2$ & 0.871443 & 147.2124 & 69.81889 & $\mathrm{r}=1$ & $\mathrm{r}=2$ & 63.59298 & 33.87687 \\
\hline $\mathrm{r}=2$ & $\mathrm{r}=3$ & 0.763305 & 83.61941 & 47.85613 & $\mathrm{r}=2$ & $\mathrm{r}=3$ & 44.67051 & 27.58434 \\
$\mathrm{r}=3$ & $\mathrm{r}=4$ & 0.539672 & 38.94890 & 29.79707 & $\mathrm{r}=3$ & $\mathrm{r}=4$ & 24.05028 & 21.13162 \\
$\mathrm{r} \leq 4$ & $\mathrm{r}=5$ & 0.234496 & 14.89863 & 15.49471 & $\mathrm{r} \leq 4$ & $\mathrm{r}=5$ & 8.283837 & 14.26460 \\
$\mathrm{r}=5$ & $\mathrm{r}=6$ & 0.192151 & 6.614791 & 3.841466 & $\mathrm{r}=5$ & $\mathrm{r}=6$ & 6.614791 & 3.841466 \\
\hline
\end{tabular}

Note: $\mathrm{r}$ denotes the number of co-integrating vector, ${ }^{*}$ denotes significance of the test statistic at $5 \%$ level.

\subsubsection{The ARDL regression model}

Auto regressive distributed lag (ARDL) is useful in analyzing economic scenarios using small sample data size. For example, a change in a variable will bring effects in another variable. Hence, change in a variable may not be immediate but will be distributed over time. Likewise, ARDL is built on several assumptions: no autocorrelation, no heteroscedasticity in data (variance and mean are constant), and data must be stationary. Therefore, ARDL will be helpful in obtaining long run relationships among variables.

The estimation results are presented in Table 5. The share price index (LINDEX) is statistically significant at 1 percent level. Other things equal, 10 percent rise in the index will cause 0.08 percent boost in per-capita GDP. This indicates that Saudis look at the directions of the capital market through the market share index. In any event, Lagged LINDEX one, two, and three periods are negative but not statistically significant and their magnitude on economic growth is reduced. As can be seen, 10 percent change in market value, market capitalization, will cause a decline in per-capita GDP by 0.074 percent. It is statistically significant at 1 percent. In this case, it is expected that capitalization will impact the growth of per-capita GDP negatively. On the other hand, liquidity affects positively the growth of per-capita GDP. The magnitude of the liquidity coefficient is minimal and not statistically significant. This finding mirrors the state of stock market and the need for fast and constructive deepening. Equally important, 10 percent increase in share issuance will contribute about 0.0016 percent to the growth of per-capita GDP. This variable had the right sign and not statistically significant. Moreover, number of share transactions is positive but not significant. Moreover, lagged number of share transactions had the right sign and statistically significant at 5 percent level. In comparison, ARDL and FMOLS tests, Table 6, supports that capitalization and liquidity negates the economic growth. The number of shares, market share index, and the share transactions influence economic growth positively. FMOLS indicates no presence of serial correlation and had the exact fit. The coefficient of determination points out that high causal relationship between dependent variable, LPGDP and independent variables, LINDEX, LRVS, LRMV, LRT and LNS are given by $\mathrm{R}^{2}$. This indicates that 99 percent of independent variables together explain the systematic variations in LPGDP. The D-W test gave a good fit and there is no presence for serial correlation problem (see, Table 10 with p-value of 0.1006 ). 
Table 5. The ARDL regression with dependent variable LPGDP

\begin{tabular}{|c|c|c|c|c|}
\hline Variable & Coefficient & St. Error & t-Statistic & Probability \\
\hline LPGDP (-1) & 0.431576 & 0.173552 & 2.486715 & $0.0322^{*}$ \\
\hline LPGDP (-2) & -0.087853 & 0.179677 & -0.488952 & 0.6354 \\
\hline LPGDP (-3) & 0.417455 & 0.169994 & 2.455706 & $0.0339^{\star}$ \\
\hline LINDEX & 0.800368 & 0.087394 & 9.158186 & 0.0000 \\
\hline LINDEX $(-1)$ & -0.207612 & 0.194839 & -1.065557 & 0.3117 \\
\hline LINDEX (-2) & -0.056033 & 0.182454 & -0.307108 & 0.7651 \\
\hline $\operatorname{LINDEX}(-3)$ & -0.276155 & 0.182133 & -1.516221 & 0.1604 \\
\hline LRVS & 0.009359 & 0.038824 & 0.241074 & 0.8144 \\
\hline LRVS $(-1)$ & -0.075943 & 0.034964 & -2.172018 & 0.0550 \\
\hline LRVS (-2) & 0.037737 & 0.023639 & 1.596397 & 0.1415 \\
\hline LRVS (-3) & -0.0192246 & 0.019467 & -0.988662 & 0.3461 \\
\hline LRT & 0.022431 & 0.035484 & 0.632142 & 0.5415 \\
\hline LRT $(-1)$ & 0.072853 & 0.027537 & 2.645647 & $0.0245^{\star}$ \\
\hline LNS & 0.015930 & 0.022964 & 0.693706 & 0.5037 \\
\hline LNS $(-1)$ & -0.006395 & 0.025112 & -0.254665 & 0.8041 \\
\hline LNS (-2) & -0.029401 & 0.019755 & -1.488266 & 0.1675 \\
\hline LRMV & -0.735309 & 0.092346 & -7.962524 & $0.0000^{*}$ \\
\hline $\operatorname{LRMV~}(-1)$ & 0.198743 & 0.196280 & 1.012552 & 0.3351 \\
\hline LRMV $(-2)$ & -0.032373 & 0.168190 & -0.192480 & 0.8521 \\
\hline $\operatorname{LRMV~}(-3)$ & 0.330637 & 0.180761 & 1.829142 & 0.0973 \\
\hline $\mathrm{C}$ & -1.407180 & 1.887445 & -0.745548 & 0.4731 \\
\hline $\mathrm{R}^{2}$ & 0.999341 & & & \\
\hline Adjusted $\mathrm{R}^{2}$ & 0.998024 & & & \\
\hline F-Statistics & 758.5526 & & & \\
\hline $\mathrm{D}-\mathrm{W}$ & 2.811202 & & & \\
\hline
\end{tabular}

Note: ${ }^{\star} \mathrm{p}$-values and any subsequent tests do not account for model selection.

Table 6. FMOLS estimates with dependent variable LPGDP

\begin{tabular}{|c|c|c|c|c|}
\hline Variable & Coefficient & St. Error & t-Statistics & Probability \\
\hline $\mathrm{C}$ & -4.615362 & 1.413384 & -3.265468 & 0.0030 \\
\hline LINDEX & 0.974162 & 0.097761 & 9.964777 & 0.0000 \\
\hline LRMV & -0.881975 & 0.105842 & -8.332967 & 0.0000 \\
\hline LRVS & -0.192993 & 0.027320 & -7.064207 & 0.0000 \\
\hline LRT & 0.120246 & 0.030442 & 3.950028 & 0.0005 \\
\hline LNS & 0.032865 & 0.018870 & 1.741640 & 0.0930 \\
\hline $\mathrm{R}^{2}$ & 0.986212 & & & \\
\hline Adjusted $\mathrm{R}^{2}$ & 0.983659 & & & \\
\hline $\mathrm{L}-\mathrm{R}$ variance & 0.004393 & & & \\
\hline
\end{tabular}




\subsubsection{The ARDL short-run, long-run and bounds testing}

Table 7 displays the short-run coefficients and the error correction model estimate $\mathrm{ECM}_{\mathrm{t}-1}$ of the ARDL model. The error correction model (ECM) has the negative sign and significant at 1 percent level. The speed of adjustment of the variables from short-run to the long-run equilibrium for the error correction model is a bit moderate and is 24 percent. The finding reflects that the last period's disequilibrium is corrected at the speed of 24 percent annually. One justification for this low speed of adjustment is the volatility of capital market due to the nature of dependence on oil windfalls. Thus, the rudimentary state of Saudi capital market adds to the cause of low speed of adjustment. According to results, the effect of the share price index (LINDEX) variable in the short and long run is positive and significant at 1 percent level. The contribution of the variable LNS is about 0.0016 percent to LPGDP due to 10 percent increase in number of shares. Moreover, the number of share transactions (LRT) has positive impact on per-capita GDP and is statistically significant at 1 percent level. Looking at the long run results, Table 8, one notices the consistency of short run and long rum effects. Capitalization and liquidity have impacted the capital market negatively. This situation raises questions about the seriousness of the efforts done by Saudi capital market authority (CMA) to develop the capital market in order to spur economic progress. For the bounds testing, Table 9, F-statistics value is about 7.01 percent which is higher than the upper bound at all levels. This indicates the rejection of null hypothesis that there exists no co-integration among all variables.

Table 7. The ARDL ECM with dependent variable D(LPGDP)

\begin{tabular}{|c|c|c|c|c|}
\hline Variable & Coefficient & St. Error & t-Statistic & Probability \\
\hline $\mathrm{D}(\operatorname{LPGDP}(-1))$ & -0.329602 & 0.105042 & -3.137822 & $0.0105^{*}$ \\
\hline D (LPGDP (-2)) & -0.417455 & 0.100322 & -4.161147 & $0.0019^{\star}$ \\
\hline D (LINDEX) & 0.800368 & 0.040567 & 19.72945 & $0.0000^{*}$ \\
\hline $\mathrm{D}(\operatorname{LINDEX}(-1))$ & 0.332188 & 0.096862 & 3.429487 & $0.0064^{*}$ \\
\hline $\mathrm{D}(\operatorname{LINDEX}(-2))$ & 0.276155 & 0.102285 & 2.699856 & $0.0223^{*}$ \\
\hline D (LRVS) & 0.009359 & 0.016504 & 0.567097 & 0.5832 \\
\hline $\mathrm{D}(\operatorname{LRVS}(-1))$ & -0.018491 & 0.014986 & -1.233907 & 0.2455 \\
\hline D (LRVS $(-2))$ & 0.019246 & 0.010385 & 1.853178 & 0.0936 \\
\hline D (LRMV) & -0.735309 & 0.0462270 & -15.89180 & $0.0000^{*}$ \\
\hline $\mathrm{D}(\operatorname{LRMV}(-1))$ & -0.298264 & 0.093571 & -3.187579 & $0.0097^{\star}$ \\
\hline D (LRMV (-2)) & -0.330637 & 0.095202 & -3.473017 & $0.0060^{*}$ \\
\hline $\mathrm{D}$ (LRT) & 0.022431 & 0.014578 & 1.538652 & 0.1549 \\
\hline $\mathrm{D}$ (LNS) & 0.015930 & 0.011677 & 1.364260 & 0.2024 \\
\hline $\mathrm{D}(\mathrm{LNS}(-1))$ & 0.029401 & 0.011604 & 2.533780 & $0.0297^{\star}$ \\
\hline Co-int. Eq (-1) & -0.238823 & 0.026955 & -8.860020 & $0.0000^{*}$ \\
\hline $\mathrm{R}^{2}$ & 0.974809 & & & \\
\hline Adjusted $\mathrm{R}^{2}$ & 0.998024 & & & \\
\hline Log likelihood & 92.70005 & & & \\
\hline $\mathrm{D}-\mathrm{W}$ & 2.811202 & & & \\
\hline
\end{tabular}


Table 8. Long run estimates with dependent variable LPGDP

\begin{tabular}{|l|c|c|c|c|}
\hline \multicolumn{1}{|c|}{ Variable } & Coefficient & St. Error & t-Statistics & Probability \\
\hline LINDEX & 1.0910553 & 0.386918 & 2.819854 & $0.0182^{*}$ \\
\hline LRMV & -0.997821 & 0.587652 & -1.697980 & 0.1204 \\
\hline LRVS & -0.201372 & 0.077620 & -2.594337 & $0.0268^{\star}$ \\
\hline LRT & 0.398977 & 0.194531 & 2.050968 & 0.0674 \\
\hline LNS & -0.083183 & 0.122462 & -0.679255 & 0.5124 \\
\hline C & -5.892156 & 6.531667 & -0.902091 & 0.3882 \\
\hline
\end{tabular}

Table 8 presents the long run estimates which conform to the short run findings. Therefore, the short-run dynamics of the ARDL estimates are stable. Test of CUSUM and CUSUMQ are implemented and indicated stability of the model as shown in Figure 3. In Table 10, Breusch-Godfrey serial correlation LM test showed no presence of serial correlation. Just as important, Table 11 revealed that there is no heteroskedasticity.

Table 9. The bounds test

\begin{tabular}{|c|c|c|c|c|}
\hline Test statistics & Value & Significant & I (0) & I (1) \\
\hline \multicolumn{3}{|c|}{ Asymptotic: $\mathrm{n}=100$} \\
\hline F-statistics & 7.008925 & $10 \%$ & 2.08 & 3 \\
\hline K & 5 & $5 \%$ & 2.39 & 3.38 \\
\hline & & $1 \%$ & 3.06 & 4.15 \\
\hline
\end{tabular}

Table 10. Serial correlation LM test

Breusch-Godfrey Serial Correlation LM Test:

Null hypothesis: No serial correlation with 2 lags

\begin{tabular}{|l|l|l|l|}
\hline F-statistics & 3.102194 & Probability F $(2,8)$ & 0.1006 \\
\hline Observed R-squared & 13.54061 & Probability Chi-square 2 & 0.0011 \\
\hline
\end{tabular}
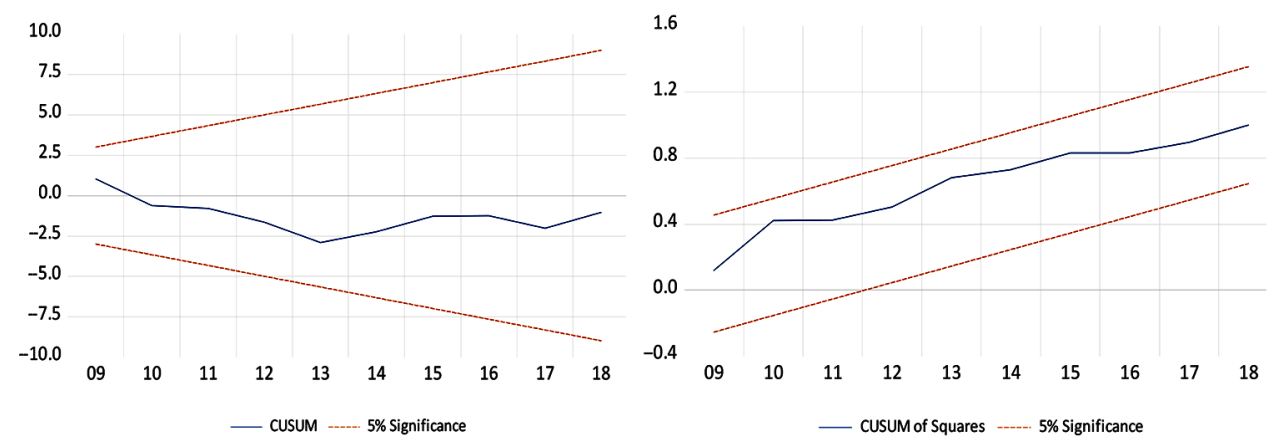

Figure 3. Cusum and Cusun squares stability tests 
Table 11. Heteroskedasticity test

\begin{tabular}{|c|c|c|c|}
\hline \multicolumn{4}{|c|}{$\begin{array}{l}\text { Breusch-Pagan-Godfrey test } \\
\text { Null hypothesis: Homoskedasticity }\end{array}$} \\
\hline F-statistics & 0.463020 & Probability F $(20,10)$ & 0.9315 \\
\hline Observed R-squared & 14.90481 & Probability Chi-square (20) & 0.7818 \\
\hline Scaled explained SS & 1.015993 & Probability Chi-square (20) & 1.0000 \\
\hline
\end{tabular}

\section{The discussion}

Based on the availability of data which is sourced from Saudi Arabian monetary agency (SAMA) yearly statistics and from capital market authority (CMA), an eclectic model has been formulated to investigate the effect of stock market on economic development in an oil-based economy. Capitalization or the size of the market, liquidity measure, number of shares, number of shares transaction, and the share price index are used as an independent variable. They regressed against the real per-capita GDP.

To carry out this work, an ARDL and FMOLS models are tested to confirm the consistency of the outcomes. Prior to perform these tests, unit root test is launched. At the integrated level of one, all variables are statistically significant at 1 percent and 5 percent level. On the other hand, Johansen co-integration (trace and max eigenvalue statistics) tests confirmed 5 co-integrated equations. From ARDL model, 10 percent increase in the stock market price share index would promote per-capita growth by 0.08 percent. This market component expresses the performance of efficiency of the stock market for investors' portfolio. It decides the direction of the stock market and plays a role in encouraging investors to take part in investment in the market. For instance, the increase in average price of shares will attract more investable funds into the market. This would yield an enhancement in financial intermediation and consequently a spur in investment and enhances economic growth. Of equal importance, other things equal, 10 percent increase in capitalization lead to a decrease in per-capita GDP by 0.074 percent. Similarly, 10 percent rise in liquidity lagged one-year would cause a reduction in per-capita GDP by 0.0075 percent. Therefore, in literature liquidity measure used by investors to confirm the stock market trend. Number of shares had the unexpected sign and is not statistically significant. Applying fully modified ordinary least square (FMOLS) confirms the results obtained from ARDL. Nevertheless, the capitalization and liquidity came with clear negative impact on per-capita economic progress and statistically significant at 5 percent. Our results are consistent with researchers' findings in economic literature where capital market negatively affects economic growth in some developing countries.

It is motivating to note, that the speed of convergence from short run to long run is 24 percent. This low speed of adjustment is justified on the grounds that capital market is volatile due to the fast changes in oil prices in world oil market. In fact, oil market is vulnerable to political and economic conditions. By the same token, long run estimates are consistent with short run findings. Causality tests revealed a unidirectional causality running from LINDEX to real per-capita GDP and unidirectional causality running from capitalization to real per-capita GDP. Furthermore, statistical tests revealed stability of the model. At last, the 
results obtained here are in line with the findings of Lei and Mishra (2016), Bakwena and Bodman (2011), Onuora (2019), Kehinde et al. (2013), Yadirichukwu and Chigbu (2014), and Alrassi et al. (2019) and others.

\section{Conclusions}

In economic literature, researchers did not conclude definite and solid answer to whether stock markets cause economic progress or not. However, the role of Saudi capital market in achieving and promoting economic development is still not encouraging. The major purpose of this research has been to analyze and estimate the effect of capital market indicators on economic development in Saudi Arabia for the period of 1985-2018. An ad hoc ARDL and FMOLS models have been developed and tested thoroughly. LINDEX is the major contributor to per-capita economic growth during the specified period. Comparatively, FMOLS results revealed consistency with ARDL findings. The $\mathrm{ECM}_{t-1}$ and the Johansen co-integration tests indicated the presence of long-run relationships among the variables LPGDP, LINDEX, LRMV, LRVS, LRT and LNS. Equally important, short-run dynamic convergence to long-run equilibrium is 24 percent. Correspondingly, the reduction of existing disequilibrium over time is of interest in order to maintain long-run equilibrium. The low speed of convergence reflects the weak ability of the capital market to advance economic growth. The fluctuation of government revenue because of instability of oil prices aggravates the weakness. It could be also attributed to the smallness and fragmented status of capital market in Saudi Arabia. On the other hand, the ratio of market value of shares to GDP, as a proxy of capitalization came up with the negative sign and statistically significant indicating the negative impact of size of the market on economic development. Similarly, the ratio of shares value to GDP, as a liquidity indicator, negates the per-capita growth. Number of shares and number of transactions came up with positive impact on per-capita economic development as expected earlier.

All in all, capital market had no significant contribution to economic advancement in Saudi Arabia regardless of efforts through vision 2030 to promote economic growth. The low participation of capital market to economic progress could be attributed to the moderate allocations to savings which will produce investors' confidence. This could happen through policies that do not differentiate between bank-based financial sector and the market-based stock economy. This step ensures financial stability which enhances capital formation, investment and hence spurs economic growth. In the same manner, government should encourage capital market authority (CMA) to deepen the capital market through stimulating private companies to register and join the market. Different barriers to enter the market should be eased. Foreign investors should be motivated to come in especially in the prevailing merit of political and economic stability.

This research is carried out despite some limitations. Lack of historical data for stock market indicators for the 70s and early 80s. Furthermore, lack of data on value of government bonds in circulation, foreign portfolio investment and some other relevant variables discussed in economic literature, could improve the results of the model under consideration. 
Government bonds in circulation increase government debt which will be sourced from capital market and hence, raises investments in infrastructure, transportation, and health projects. To see the impacts of capital market development on economic expansion, it is desirable to extend this paper to include the stock market turnover as an independent variable. Applying turnover necessitates collecting data on daily or quarterly basis for all variables for better understanding of the behavior of the market. In addition, an interesting extension of this study should cover Gulf Cooperation Countries (GCC): Saudi Arabia, Oman, United Arab Emirates, Qatar, Kuwait and Bahrain. These economies share economic, cultural, and structural environment.

\section{Disclosure statement}

I declare that I do not have any competing financial, professional, or personal interests from other parties.

\section{References}

Abina, A., \& Maria, L. (2019). Capital market and performance of Nigerian economy. International Journal of Innovative Finance and Economic Research, 7(2), 51-66.

Acha, I., \& Akpan, S. (2019). Capital market performance and economic growth in Nigeria. Nobel International Journal of Economics and Financial Research, 4(2), 10-18. http://napublisher.org/?ic=journals\&id=2.

Ailemen, I., Cynthia, I., Touchukwu, O., \& Areghan, I. (2016). An investigative analysis into capital market and economic growth in Nigeria, Ekonomske Praksa Broj, 23.

Alam, Md., \& Hussein, M. (2019). The impact of capital market on the economic growth in Oman. Financial Studies, 2, 116-129.

Alghfais, M. (2016). Comparative analysis: The impact of financial sector development on economic growth in the non-oil sector in Saudi Arabia (SAMA Working Paper WP/16/5). Saudi Arabian Monetary Agency.

Alrassi, M., Alsabban, S., \& Alarfaj, O. (2019). Does stock market performance affect economic growth? Evidence from Saudi Arabia (SAMA Working Paper WP/19/06). Saudi Arabian Monetary Agency. https://doi.org/10.5539/ijef.v11n9p21

Bader, O. (2015). Stock market development and economic growth: Evidence from Egypt. International Journal of Trade, Economics and Finance, 6(2).

Bakwena, M., \& Bodman, P. (2011). The role of financial development in natural resource abundant economies: Does the natural resource matter? BOJE: Botswana Journal of Economics, 7(11), 16-31. https://doi.org/10.4314/boje.v7i11.64201

Benczur, P., Karagiannis, S., \& Kvedaras, V. (2019). Finance and economic growth: Financing structure and non-linear impact. Journal of Macroeconomics, 62, 103048.

https://doi.org/10.1016/j.jmacro.2018.08.001

Bist, J. (2017). Stock market development and economic growth in Nepal: An ARDL representation. Journal of Finance and Economics, 5(4), 164-170.

Brasoveanu, L., Dragota, V., Catarama, D., \& Semenescu, A. (2008). Correlations between capital market development and economic growth: The case of Romania. Journal of Applied Quantitative Methods, 3(1), 64-75. 
Caporale, G., Rault, C., Sova, R., \& Sova, A. (2009). Financial development and economic growth: Evidence from ten new EU members (Economic and Finance Working Papers Series No. 09-37). Brunel University and CESifo \& DIW Berlin. https://doi.org/10.2139/ssrn.1499786

Cevik, S., \& Rahmati, M. (2013). Searching for finance-growth nexus in Libya (IMF Working Paper WP/13/92). International Monetary Fund. https://doi.org/10.5089/9781484385883.001

Coskun, Y., Seven, V., Ertugral, H., \& Ulussever, T. (2017). Capital market and economic growth nexus: Evidence from Turkey. Central Bank Review, 17(1), 19-29. https://doi.org/10.1016/j.cbrev.2017.02.003

Edweib, A., Shafii, Z., \& Ahmad, N. (2013). Stock market and economic growth in Libya. IOSR Journal of Economic and Finance, 2(1), 43-51. https://doi.org/10.9790/5933-0214351

Flaviabarna, P., \& Mura, O. (2010). Capital market development and economic growth: The case of Romania. Annals of the University of Petrosani Economics, 10(2), 31-42.

Fisman, R., \& Love, I. (2004). Financial development and growth in the short and long run (NBER Working Paper No. 10236). National Bureau of Economic Research. https://doi.org/10.3386/w10236

Havranek, T., Horvath, R., \& Valickova, P. (2013). Financial development and economic growth: A meta-analysis (Working Paper No. 5). Czech National Bank. http://www.cnb.cz

Hjalmarsson, E., \& Österholm, P. (2007). Testing for co-Integration using the Johansen method when variable near-integrated (IMF Working Paper WP/07/101). International Monetary Fund. https://doi.org/10.5089/9781451867053.001

Ho, S., \& Odhiambo, N. (2020). The macroeconomic drivers of stock market development: Evidence from Hong Kong. Journal of Financial Economic Policy, 12(2), 185-207. https://doi.org/10.1108/JFEP-11-2018-0163

Ho, S. (2019). Macroeconomic determinants of stock market in South Africa. International Journal of Emerging Markets, 14(2), 322-342. https://doi.org/10.1108/IJoEM-09-2017-0341

Ibrahim, M. (2013). Financial development and economic growth in Saudi Arabian economy. Applied Econometrics and International Development, 13(1), 133-144.

Idenyi, O., Ifeyinwa, A., Samuel, O., \& Cibuzor, C. (2017). Capital market indicators and economic growth in Nigeria: An Autoregressive Distributed Lag (ARDL) model. Asian Journal of Economics Business and Accounting, 2(3), 1-16. https://doi.org/10.9734/AJEBA/2017/32549

Iheanacho, E. (2016). The impact of financial development on economic growth in Nigeria: An ARDL analysis. Economies, 4(26), 1-12. https://doi.org/10.3390/economies4040026

Ikikii, S., \& Nzomoi, J. (2013). An analysis of the effects of the stock market on economic growth in Kenya. International Journal of Economics and Finance, 5(11), 145-151. https://doi.org/10.5539/ijef.v5n11p145

Jamil, T., \& Shazia, F. (2013). Capital market deepening and economic growth in Bangladesh. Studia Universitatis Babes Bolyai - Negotia, 58(2), 21-32.

Kargbo, S., \& Adamu, P. (2009). Financial development and economic growth in Sierra Leone. Journal of Monetary and Economic Integration, 9(2), 30-57.

Kehinde, A., Ademola, I., Kayode, K., Felix, A., \& Musibau, O. (2013). Capital market and economic growth in Nigeria: An empirical analysis. IOSR Journal of Humanities and Social Science, 6(6), 60-68. https://doi.org/10.9790/0837-0666068

Khetsi, Q., \& Mongale, I. (2015). The impact of capital market on the economic growth in South Africa. Journal of Governance and Regulations, 4(1), 154-163. https://doi.org/10.22495/jgr_v4_i1_c1_p6

Kolapo, F., \& Adaramols, A. (2012). The impact of the Nigerian capital market on economic growth. International Journal of Developing Societies, 1(1), 11-19.

Lei, P., \& Mishra, V. (2016). Stock market development and economic growth: Empirical evidence from China (Department of Economics Discussion Paper 16/16). Monash Business School. 
Lenee, T., \& Oki, J. (2017). Capital market development and economic growth: Evidence from MINT countries. Journal of Economics and Sustainable Development, 8(2), 68-107.

Levine, R. (1997). Financial development and economic growth: Views and agenda. Journal of Economic Literature, 35(2), 688-726.

Masoud, N. (2013). The Impact of stock market performance upon economic growth. International Journal of Economic and Financial Issues, 3(4), 788-798.

Mhadhbi, K. (2014). Financial development and economic growth: A dynamic panel data analysis. International Journal of Econometrics and Financial Management, 2(2), 48-58.

Mukundi, A. (2013). The relationship between financial deepening and gross domestic product in Kenya: A case of NSE listed financial institution [MA Thesis]. University of Nairobi.

Nkro, E., \& Uko, A. (2016). Autoregressive distributed lag (ARDL) co-integration technique: Application and interpretation. Journal of Statistical and Econometric Methods, 5(4), 63-91.

Nordin, S., \& Nordin, N. (2016). The impact of capital market on economic growth: A Malaysian outlook. International Journal of Economics and Financial Issues, 6(S7), 259-265.

Nwamuo, C. (2018). Impact of capital market on economic growth in Nigeria: An empirical analysis. IOSR Journal of Economics and Finance, 9(5), 48-59.

Nwani, C., Iheanach, E., \& Okogbue, C. (2016). Oil price and the development of financial intermediation in and developing oil-exporting countries: Evidence from Nigeria. Cogent Economics Finance, 4, 1185237. https://doi.org/10.1080/23322039.2016.1185237

Okene, K., \& Ndubuisi, P. (2017). The role of stock market development on economic growth in OPEC countries: Does oil price movement matter? Fresh evidence from Nigeria. Asian Journal of Economic Modelling, 5(2), 194-207. https://doi.org/10.18488/journal.8.2017.52.194.207

Okoh, J. \& Eke, R. (2015). Capital market and economic growth nexus: Evidence from Nigeria. IOSR Journal of Business and Management, 17(11), 31-38.

Onuora, O. (2019). Effects of capital market on economic growth and development of Nigeria (20002017). International Journal of Academic Research in Business and Social Sciences, 9(2), 211-220. https://doi.org/10.6007/IJARBSS/v9-i2/5535

Oprea, O., \& Stoica, O. (2018). Capital markets integration and economic growth. Montenegrin Journal of Economics, 14(3), 23-35. https://doi.org/10.14254/1800-5845/2018.14-3.2

Osakwe, C., \& Ananwude, A. (2017). Stock market development and economic growth: A comparative evidence from two emerging economies in Africa-Nigeria and South Africa. Archives of Current Research International, 11(1), 1-15. https://doi.org/10.9734/ACRI/2017/38116

Osamwonyi, I., \& Kasimu, A. (2013). Stock market and economic growth in Ghana, Kenya, and Nigeria. International Journal of Financial Research, 4(2), 83-98. https://doi.org/10.5430/ijfr.v4n2p83

Osho, A. (2014). The role of stock market on Nigeria's economic development. International Journal of Scientific and Research Publications, 4(4), 1-7.

Ouandlous, A. (2010). Capital market and economic development: A framework for newly liberalized Economies. Journal of Business and Economics Research, 8(6), 9-16. https://doi.org/10.19030/jber.v8i6.728

Pesaran, H., \& Shin, Y. (1999). An autoregressive distributed lag modelling approach to cointegration analysis. In S. Strom (Ed.), Econometrics and Economic Theory in the $20^{\text {th }}$ Century the Ragnar Frisch Centennial Symposium (pp. 371-413). Cambridge University Press.

Qamruzzaman, Md. \& Wei, J. (2018). Financial innovation, stock market development and economic growth: An application of ARDL model. International Journal of Financial Studies, 6(69), 1-30. https://doi.org/10.3390/ijfs6030069 
Quixina, Y., \& Almeida, A. (2014). Financial development and economic growth in a natural resourcebased economy: Evidence from Angola (FEP Working Paper No. 542). http://wps.fep.up.pt/wps/wp542.pdf

Rahman, A., Khan, M., \& Charfeddine, L. (2020). Financial development-economic growth nexus in Pakistan: New evidence from the Markov switching model. Cogent Economics and Finance, 8, 1-15. https://doi.org/10.1080/23322039.2020.1716446

Samargandi, N., Fidrmue, J., \& Ghosh, S. (2014). Financial development and growth in an oil-rich Economy. Economic Modelling, 43(C), 267-278. https://doi.org/10.1016/j.econmod.2014.07.042

Saudi Arabian Monetary Agency. (2019). Yearly statistics, 2019.

Schumpeter, J. A. (1911). The theory of economic development. Harvard University Press.

Srinivasan, P. (2014). Stock market development and economic growth in India: An Empirical analysis. MPRA.

Twerefou, D., Abbey, E., Codjoe, E., \& Ngotho, P. (2019). Impact of stock market development on economic growth: Evidence from selected Sub-Saharan African Countries. Acta Universitatis Agriculturae Et Silviculturae Mendelianae Brunensis, 67(93), 1071-1083. https:/doi.org/10.11118/actaun201967041071

Wanaset, A. (2018). The relationship between stock market and economic growth in Thailand. Journal of Economics and Management Strategy, 5(1), 25-38.

Yadirichukwu, E., \& Chigbu, E. E. (2014). The impact of capital market on economic growth: The Nigerian Perspective. International Journal of Development and Sustainability, 3(4), 838-864. https://doi.org/10.14738/abr.34.1379 